
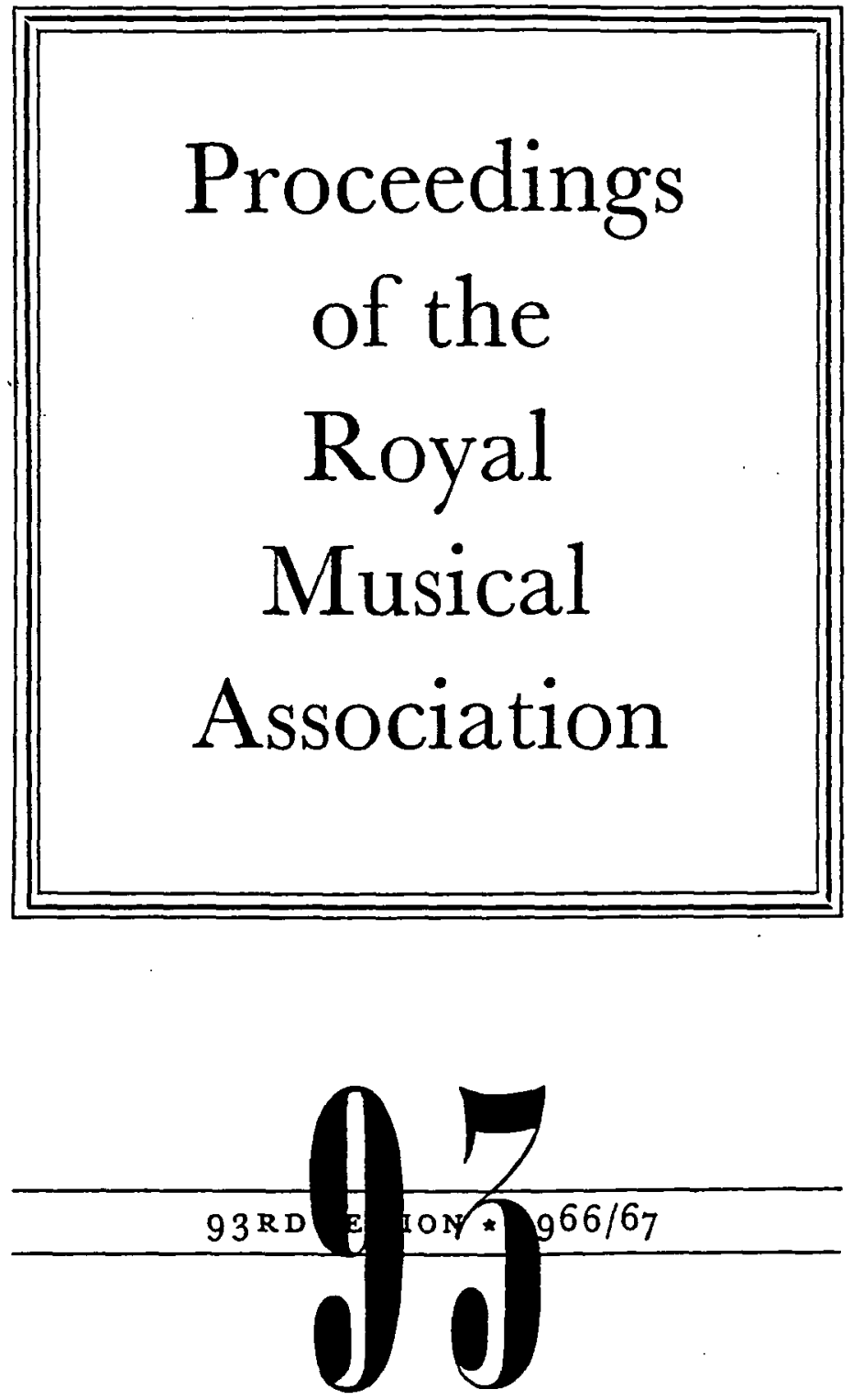


\section{Reprinted with the permission of THE ROYAL MUSICAL ASSOCIATION LONDON KRAUS REPRINT ITD. Vaduz 1966}




\section{6- 1967 \\ Proceedings}

\section{Contents}

I6 November 1966: DONALD PEART

The Australian Avant-Garde

page I

I4 December 1966: JOHN CALDWELL

The Organ in the Medieval Latin Liturgy, 800-1500 page $I I$

5 January 1967: BRIAN JEFFERY

The Lute Music of Antony Holborne

page 25

IO January 1967: JEROME ROCHE

The Duet in early seventeenth-century Italian

Church Music

I4 March 1967: ElizaBeTH NORMAN McKAY

Schubert's Music for the Theatre

14 April rg67: RAYMOND LEPPARD

Cavalli's Operas

15 April 1967: JOSEPH KERMAN

Beethoven Sketchbooks in the British Museum

15 April 1967: David Wulstan

The Problem of Pitch in sixteenth-century English

Vocal Polyphony

page 97

Details of offprints published by Musica Britannica may be found on page 127 . 


\title{
The Royal Musical Association
}

POONDED 28 YAY I874 (INCORPORATED I9O4)

Members may submit suggestions for papers on subjects of which they have specialist knowledge. Such suggestions should be addressed to the Secretary.

\author{
Secretary: Dr. Nigel Fortune, \\ 44 Philip Victor Road, \\ Handsworth, \\ Birmingham, 2I
}

(to whom $A L L$ communications, except those concerning finance, should be addressed)

The Proceedings is published at thirty shillings

(C) 1967 The Royal Murical Association and the Authors 


\title{
R.M.A. RESEARCH CHRONICLE
}

\author{
No. I $(\mathrm{rg} 6 \mathrm{I})$
}

pp. vii +107

мachat tilmouth: A Calendar of References to Music in Newspapers published in London and the Provinces (1660-1719)

Errata and Index to No. I

$$
\text { No. } 2 \text { (1962) }
$$

pp. 57

BRIAN FAGAN: 'The name's the same', or: A Warning to Searchers

HuGH Ballie: Some Biographical Notes on English Church Musicians, chiefly working in London ( $1485-1560)$

$$
\text { No. } 3(1963)
$$

pp. $v i+5^{8}$

PAUL DOE: Register of Theses on Music (at British universities since 1945) NIGE Fortune: A Handlist of printed Italian secular Monody books, $1602-1635$

HORACE FITZPATRICK: The Waldhorn and its associations in Bach's time DON FRankun : Five Manuscripts of Church Music at Lichfield

$$
\text { No. } 4(1964)
$$

pp. $v i+98$

Richard Rastall: The Minstrels of the English Royal Households, 25 Edward I-I Henry VIII : an Inventory

ALAN SMITH: Parish Church Musicians in England in the reign of Elizabeth $I$ (1558-1603): an annotated Register

PAUL DOE: Register of Theses on Music: Amendments and Additions

$$
\text { No. } 5(1965)
$$

pp. iv +84

LeNore coral: A John Playford Advertisement

ALAN smrrH: The Gentlemen and Children of the Chapel Royal of Elizabeth I: an annotated Register

JEROME ROCHE: An Inventory of Choirbooks at S. Maria Maggiore, Bergamo, January 1628

DOUGLAs J. REID (assisted by Brian Pritchard): Some Festival Programmes of the Eighteenth and Nineteenth Centuries. 1. Salisbury and Winchester WYN K. FORD: Some Wills of English Musicians

$$
\text { Nos. } 6(1966) \text { and } 7(1967) \text { in course of preparation }
$$

To members: $10 / 6$ ( $\$ 1.60)$

To others: $16 /-(\$ 2.40)$

Standing orders welcomed

CLASSIFIED CONTENTS LIST TO PROCEEDINGS, VOLS. 1-90

In three sections: by Author; by Subject; Chronologically

To members: $15 /-(\$ 2.30)$

To others: $30 /-(\$ 4.20)$

Applications for copies of these publications and for full details of membership to the Secretary at the address shown opposite

Sperial tarms to the book trade 